\title{
Women in Igbo Traditional Religion and Politics: Prospects for Women's Political Leadership Role in Nigeria
}

\author{
Michael Muonwe \\ http://dx.doi./org/10.4314/ujah.v20i3.1
}

\section{Abstract}

The struggle for political visibility, participation, and leadership of women has been a recurrent issue in all societies, including the most developed democracies. Whereas an appreciable improvement has been recorded in many western countries, Africa still ranks low generally as far as gender inclusivity in political leadership is concerned. Some scholars on Igbo society and culture cling to the popular opinion of blaming this scenario on colonialism. Such scholars usually paint an image of an ideal, precolonial, egalitarian Igbo society where women were more or less accorded more political and leadership space than in the present. In their opinion, reclaiming the past is a sure way to better gender inclusivity in politics. This paper is designed to interrogate critically such images of the past Igbo society. The author approaches the paper with the belief that such romantic view of the past, if not cautiously guided and critically appraised, may well result in nostalgia for a past that never was. The paper aims at hermeneutical-critical reading of women's visibility and/or invisibility in the pre-colonial Igbo political leadership landscape, with the view of presenting a possible link of the present situation with the past, as well as tracing from this a path for the future of women's political visibility, participation, and leadership in Nigeria.

Keywords: Igbo, women, politics, leadership, colonialism 


\section{Introduction}

According to a recent survey by the United Nations Women (2019), women occupied only $24.3 \%$ of parliamentary seats worldwide. Rwanda, Cuba, and Bolivia are the only countries that have $50 \%$ or more women in their houses of parliament. Rwanda records the highest percentage of women parliamentarians. They account for $61.3 \%$ of the seats in their lower house of parliament. Across the regions, Americas has the highest percentage of women representation $(30.6 \%)$, followed by the sub-Saharan Africa (23.9\%), then Asia (19.8\%), Arab States (19\%), and lastly, the pacific, which has the lowest (16.3\%).In 27 countries, including Nigeria, women do not have up to $10 \%$ parliamentary representation. As at June 2019, women serving as Heads of States worldwide were 11, while those serving as Heads of Governments were 12.

According Nigeria's National Bureau of Statistics (2018), from 1999-2015, Nigerian women occupied 5.8\% of the seats at the national houses of parliament, and 5.3\% at the State level. As chairpersons and councillors of the Local Governments, they accounted for $9 \%$ and $5.9 \%$ respectively within the period. In the judiciary, they constitute $29.4 \%$ of the judges at the federal courts. No woman has ever served as the president or the vice president of the country.

Given the above national statistics, many researchers, especially of Igbo extraction, have been forced to compare the status quo with what obtained before colonialism. Their conclusions often suggest that Igbo women were better off politically in the pre-colonial era than in the present. The likes of Nzegwu (2006), Agbasiere (2000), Amadiume (1987, 1997), Okonjo (1976), and Chuku (2009), argue for recovering what they regard as political, economic, or socio-religious powers of Igbo 
women that seem to have been undermined overtime. They seem to view the pre-colonial era as the golden age of egalitarian principles in Igbo society. Some even posit that the current pervasive practice of sexism in the society was minimally existent before the arrival of British colonisers and Christian missionaries. Even when they acknowledge the age-old nature of some of the sexist elements within the society, they appear to do so reluctantly.

Reference is often made to such Igbo women in the past who held leadership positions in their respective communities, like the omu of Onitsha (Henderson, 1972; Mba, 1982), Ezenwayi of Oru area (Jell-Bahlsem, 1998), Agba Ekwe of Nnobi (Amadiume, 1987). Others discuss the strength of women groups, such as umuada or umuokpu and ndi inyomdi.

Okonjo (1976) argues that it was within the colonial period that Igbo women "suffered the greatest loss of power." Nzegwu (1995) describes colonialism as an alienating experience for Igbo women, arguing that it took away their political voice and visibility. Hence, the assertion of Lebeuf (1976) that the present lack of interest in politics by African women is not a heritage of their pre-colonial past.

This paper examines critically some of the aspects of the precolonial Igbo women's political visibility, participation, and leadership that are regarded as those of strength by these Igbo authors, to assess how they can or cannot function to encourage women in the present Nigerian society to do more for active involvement in politics and governance.

\section{Patriarchal Pre-independence Constitutional Monarchy}

Igbo society had two major variants of political organization on the village-group (town) level in pre-colonial era. The first was constitutional monarchy, found in few communities, like Onitsha 
and Oguta. This system, Orji (2007) and Uchendu (1965) argue, was not original to Igbo people, but were intrusions from other neighbouring communities. In those few Igbo communities where it functioned, the people were usually ruled by a king (monarch) and a group of titled men (ndichie). Some of them, according to Chuku (2009), were also known to have been ruled at some point by a queen. Chuku maintains that, for a woman to have occupied such a position, shows that the then Igbo society offered women an appreciable space for political and social mobility and visibility. She nevertheless appears not to have appreciated enough the paucity of those instances compared to what obtained in the greater part of Igbo society.

The other system of governance found in more than $80 \%$ of the pre-colonial Igbo society was direct democracy, which was more decentralised and participatory. In this system, the political power was somehow more diffuse; the importance of elders, titled men, patrilineage and family heads, age-grades, women groups, were stressed. The village was more politically relevant than the village-group. People gathered in the village square to discuss issues and enact laws. No single individual could dictate for others or lord it over them. One's effectiveness as a leader and the validity of any legislation lay principally on how everybody was carried along. In most of the villages, only adult males attended the village assembly - where matters of general concern were dealt with - while in some others, few women also participated (Uchendu, 1965). Though those women might be allowed to express their opinions, especially on matters that directly affected them, it was the responsibility of male elders, who were the leaders of their respective families and clans, to make the final decision. This shows that the system was patriarchal at this period. 
On the village-group level, a sort of "representative assembly" was formed in which each of the component villages had equal voices. The power of the village-group was based on the consensus of the component villages. People were selected to stand for their specific villages whenever there was a felt need for an assembly; there was nothing like permanent membership. Moreover, the selectees merely had "'delegate' and not a 'representative' status," thus could not "commit their village to any matter not previously discussed and agreed upon by it" (Uchendu, 1965 , p. 44). These levels served the people both in the judicial, legislative, and executive capacities; their authority was derived from the traditional religion and was, therefore, regarded sacred (Orji, 2007).

On these levels again, men played active part, while women were only allowed to make contributions mostly on invitation. The onus lay on male elders to take final decisions. This again shows that men dominated the political space during the precolonial period.

\section{Dual-Sex Political Arrangement}

Chuku (2005) has described the Igbo political arrangement in precolonial time as mainly dual-sex, where women controlled the affairs relevant to them, while men took charge of issues relating to the community in general. According to her, the arrangement ensured maintenance of an effective division of labour, political governance, and participation along gender lines, and helped to pursue balance of political power. What Chuku seems to have glossed over is that, since men legislated on issues bordering on the entire community, their decisions usually overrode those taken by women, especially when the two were in conflict. 
Onitsha was an ideal instance where the so-called dual-sex political arrangement is said to have worked very well. The political structure of their monarch, Obi, seemed to run parallel to that of omu, who controlled the affairs of women. Just like the Obi, with his own councillors called ndichie, Omu had her councillors known as ndi-otu-ogene. According to Mba (1982), for someone to be enthroned Omu, she must be in her post-menopausal age. Henderson (1972) reveals that she must be the head-daughter (isi$a d a$ ) of the royal clan. Her councillors should also be the isi-ada of their respective clans. Being the isi-ada made them be considered as quasi-males, on account of which they would be able to hold the cultic symbol of justice in Igbo society, ofo (in their case, of $\frac{\rho}{\text { isi- }}$ $a d a$, which women were ordinarily not allowed to touch nay hold. Each of them got her respective $o f o$ from her clan priests and held them on delegated capacity.

Omu's political relevance in Onitsha explains why Omu Nwagboka, the last Omu who reigned from 1884-1886, was one of the signatories to the treaty made on 9 October 1884 between Onitsha and Queen Victoria of England (Mba, 1982).

\section{Asymmetrical Power Relations in Dual-Sex Structure}

Despite appearances to the contrary, it must be observed that Omu's political significance in Onitsha went as far as it mirrored that of Obi. According to Henderson (1972), because of her position, $O m u$ and her councillors had the tendency to assume male titles and prestige symbols, and that she had at times so widely rivalled Obi that she endangered his office.

Again, the fact that the head-daughters were considered eligible to hold ofo because they were considered quasi-males makes issues more disturbing. If the acquisition and possession of the cultic symbol, $o f o$, was considered as men's special domain, 
one wonders whether women's acquisition of their own cultic symbol of justice would not have been a better possibility than their having to be considered males and less females in order to be allowed to acquire and possess ofo. Chuku (2005) brings out the issue more sharply when she asserts: "Age elevated some women, especially postmenopausal ones, from females to males, a status that gave them opportunity to participate in certain ceremonies that were the exclusive preserves of males" (p. 8).

Additionally, the issue of ritual uncleanness traditionally attached to menstruation needs to be interrogated. It was on account of it that women were not allowed to assume the position of Omu or her councillors until they reached postmenopausal age. Besides, while men held their ofo as a symbol proper to their offices, women held theirs (that seemingly denies them of their identity) in delegated capacity. In all, it suffices to surmise that, even though women of Onitsha did enjoy some level of political participation in pre-colonial times, which could be considered better than that enjoyed by women in most parts of Igbo society, their involvement was nothing near being symmetrical to that of men, as some have claimed.

\section{The Power of Patrilineage Daughters (ym uada)}

Every clan, village, and town in Igbo society has basically two women associations that wield some political (and religious) power and influence, namely otu umuada or otu umuokpu and otu nwunyedi. While the former comprises all women - married, unmarried (but had reached marriageable age), divorced or widowed - who were bona fide daughters of a particular clan, village or town, the latter comprises all the wives of their men. These two groups were stronger in the pre-colonial period than they are today. 
Otu umuada usually wielded greater authority than otu nwunyedi. Traditionally, Igbo men would generally be more inclined to listen to their sisters than they would their wives. Thus, in her natal home, a woman wielded more power and control of events than the wives of her brothers. As a married woman, she was considered as someone who had gone on an errand, and who would often refer to her natal home in moments of difficulty, and would definitely be brought home at death for burial. In this wise, Okonjo (1976) notes, "Igbo women had few rights in their marital villages. Though their children had full membership in the lineage, they themselves continued to be regarded as strangers. Consequently, they looked back to their natal villages as their only real homes when they needed shelter and succour" (p. 52-53).

Ndi nwunyedi usually address umuada as ndi di anyi (our husbands). The latter addressed the former as ndi nwunye anyi (our wives), indicating their lower standing (Okonjo, 1976). This will become clearer if one understands the meanings of $d i$ and nwunye in Igbo Language. $D i$, as Henderson (1972) remarks, fundamentally means someone who has authority and control over another. $D i$ could also be used as a prefix to characterise someone who possesses a high degree of skill and professionalism in some areas of life. For instance, someone very skilful in cultivating yam is called diji - literally, "the husband of yams," implying that yam responds very well to his command. Other words formed with the prefix, $d i$, in Igbo Language to denote masterful control include diogu (expert in wrestling), diochi (expert in wine-tapping), dimkpa (very strong man), dinta (master in the art of hunting). Within the context of the family, as Amadiume (1987) notes, when one wishes to express pointedly the husband's headship and control over his entire household, $d i$ is normally prefixed to buno, hence, dibuno - the master/head of the household. 
Nwunye (wife) denotes someone in a subordinate position in relation to the husband. Another word for wife, onyebe (onye person; $b e$ - of the home), means someone who is a member of a household where another (the husband in this case) is in-charge. Henderson (1972) observes that the two words, husband and wife, in Igbo Language, have meanings that imply "a combination of masterful control and responsibility [that is, husband $-d i$ ] on the one hand, compliance [wife - nwunye or onyebe] on the other" ( $p$. 215). The wife, therefore, submits to the authority of the husband and stays under his service. Thus, one can understand an Igbo woman addressing her husband as nnamukwu (my lord/master). In this connection, Okeke (1984) writes, "a husband in Igbo traditional society is a lord (baal) of his wives. Wives rarely call their husbands by their names. They call them 'Nna anyi,' our lord and master" (p. 140). oga $m$ (my master) is another word a wife could use for her husband.

As a group, otu umuada generally enjoyed a lot of immunity in pre-colonial times. Their influence and power helped to control the excesses of male political administration in their agnatic villages (Nzegwu, 1995). They used a lot of avenues to press home their demands in their communities. These included strikes, boycotts, group nudity (ibo ike), demonstrations (ngagharịiwe), "sitting on" or "making war on" on a person/people. The last one - "sitting on" or "making war" on a person/people entailed:

gathering at his compound, sometimes at night, dancing, singing scurrilous songs which detailed the women's grievances against him and often called his manhood into question, banging on his hut with pestles women used for pounding yams, and perhaps demolishing his hut or plastering it with mud and roughing him up a bit... The 
women would stay at his hut throughout the day, and late into the night, if necessary, until he repented and promised to mend his ways (Allen, 1972, p. 170).

The "Igbo Women War" (Ogu Umunwanyi Igbo) of 1929, termed "Aba Women Riot" by some authors, was an instance of what Igbo women regarded as "making war" on people. They organized this as a form of resistance and protest against what they thought was an attempt to enforce direct taxation on women by the colonial officers and the Warrant Chiefs in the face of difficulties experienced by their families arising from the fall in the prices of palm oil and rise in the prices of imported products. In anger, the women ravaged the houses of some of the Warrant Chiefs, mobbed and deposed some, disrupted proceedings in some of the Native Courts, assaulted some officers, looted some European trading stores among other things. The incident spread like wild fire and covered an area that was estimated to be approximately 6,000 square miles with a population of about two million. The women that participated numbered past 25,000 (Allen, 1972; Nwaguru, 1978; Muonwe 2016).

This shows that Igbo women had their strength in their group solidarity, which, unfortunately they have lost in the present Igbo society and this has affected their socio-political position and participation.

\section{Social Devices and Privileges}

Scholars also allude to some social devices and privileges enjoyed by women in pre-colonial times as giving them more political advantage than the present. Their involvement in some social and religious organizations, like secret societies, age-grades, and title societies, some of which are no longer in existence in many Igbo 
communities, it is argued, made them enjoy some political privileges. Chuku (2009) cites Iyamba women cult of Aro people, which, according to her, ran parallel to that of their men. In all the clans of Aro people, she notes, Iyamba had women heads, who had significant stakes in regulating the relationship between men and women in the community. In their judicial administration, Iyamba inflicted punishments on both male and female offenders. On anyone who flouted their orders, they would always invoke the supernatural forces of their Iyamba cult believed to bring bad fortunes to the person.

These associations offered avenues for enhancement of women's status in the society and their political influence, as well as provided occasions for exercise of their religious power. Through them, women were able to secure access to some benefits, which they would not have enjoyed ordinarily in the society as women: "Some of the women members were seen as 'males' who consequently enjoyed certain privileges that were denied noninitiates. Such privileges included admittance into exclusive men's societies..." (Chuku, 2009, p. 86). In some communities, like Oguta, such women could be allowed the privilege to break and share the kola nut; a task they were ordinarily not allowed to undertake.

\section{Male Daughters and Female Husbands}

These terms are used by Amadiume (1987) to designate the cultural practice in pre-colonial period, which still exists minimally in Igbo society of today, where an unmarried daughter assumed the roles traditionally assigned to sons in her family. Such situations usually arose when the parents did not have a male child to take over from the father when he died. One of the daughters would assume the position of a son ("male daughter") and made to stay at 
home without getting married, in order to beget children for her late father, with the hope that a male child may be born to take over from his grandfather. In a situation where, for instance, the "male daughter" fails to beget a son, she may marry another woman. She is now regarded as "female husband" who now has a wife. Other situations could also arise that may make a woman marry another woman, like the death of one's husband without a son. When it does happen, a man from her extended family or clan is usually chosen to fulfil the sexual responsibilities to the married woman (in an effort to give birth to a son).

\section{Prospects for Women's Leadership Role in Nigeria}

Okeke-Ihejirika (2004) describes the current situation of Igbo women, especially the career ones, as "a hybridised social order" (p. 4) resulting from a combination of western and indigenous factors. She acknowledges that external factors have helped to influence the production of the current asymmetrical power relations with regard to gender dynamics and the ensuing subordinate position occupied by Igbo women. But she also believes, and rightly so, that Igbo culture had been patriarchal prior to such external influences. The point is that the current oppressive and sexist practices in the society are deeply connected with, and are directed by, certain ideas, myths, and beliefs. Thus, any contribution to its improvement must realise that, unless these underlying ideas, myths, and beliefs are confronted and challenged, one may end up scratching at the surface; and one's solutions would most certainly be tangential.

The most recent conceptualisations of culture by the majority of scholars tend towards understanding culture as being primarily a reality in the mind of a particular people, which is then manifest in behaviour - a kind of mental plan or map with which a 
given people are guided in their effort to confront the challenges posed by their environment (Luzbetak, 1998; Shweder, 2001; Tanner, 1997). For one to neglect these ideational dimensions of life and presume that he or she has penetrated a people's culture is, to say the least, unrealistic. An Igbo adage has it that "if one sees a creature dancing on top of a river, he or she should know that there is most likely to be some other thing underneath the water providing the music." One implication of this is that, if one wants to achieve much success in influencing the dancing pattern of the dancer or to stop the dance, he or she should endeavour to reach out to the submarine music provider.

First, a sustained, critical research into blood symbolism and significance in Igbo culture must be undertaken. It needs to be questioned why blood that, among other things, signifies life should be understood as defiling women and making them incapable of assuming certain positions and performing certain functions in the society. In the case of councillors, they needed to reach menopause before they could occupy such positions. All these happened because there were a lot of myths and beliefs surrounding menstrual blood among the Igbo. There is need for demythologization and deconstruction in this regard. Even today, some titled men still do not want their menstruating wives to cook for them. To do so would be an abomination.

There is ingrained male hegemony and supremacy ideology that give preference to males in the society. These are deeply rooted in the culture and tradition of the Igbo. That is why the political landscape in the pre-colonial and post-colonial Igbo society is dominated by men. Few women who occupy leadership positions in politics are seen as exceptionally brave and deeply connected. The foothold of the male hegemony and supremacy 
ideology is so strong that preference for male child has driven families apart, bred hatred, suspicion, malice, and rivalry among married couples, brothers, sisters, and other relations. This begins from the family and builds itself up to the wider Igbo society. This explains why, in the precolonial village assembly, the decisions of adult males were considered supreme, while women counted no more than having consultative voice. In the present Igbo society, the meeting of umunna and the village assembly is still predominantly male affairs.

It is true that Nigeria has witnessed great political leadership roles played by some women in different areas of governance, especially in recent times, this is grossly inadequate as the statistics in the introductory section of this paper shows. Capacity-building for women specifically directed to boosting women's participation and leadership in politics must be seriously pursued. The $180^{\text {th }}$ position occupied by Nigeria out of 193 countries ranked in female representation in parliament is very worrisome (International Parliamentary Union, 1 Feb. 2019).For more than a decade the National Gender Policy of the country highlights the right of women to equality in economic, sociocultural and political life. There are also provisions to increase their number in elected and appointed positions to $35 \%$. All these seem to end in paper. The many protocols, international conventions which Nigeria is signatory to, and amendments to the Nigerian constitution undertaken over time, and intended to ensure more participation of women in politics are not followed up for implementation. This feeds on the traditional patriarchal structures in the society that need critical evaluation and dismantling.

There is the need to realize that all human beings have equal dignity, male and female alike. The Igbo word for the human person, mmadu, meaning the "good that is" (Edeh, 1985, p.10), "let 
there be goodness" (Obiego, 1984, p. 65; Arazu, 1978, p. 112116 ), the beauty or goodness of life (Isiguzo, Ukagba \& Otakpor, 2004, p.233; Okafor, 1982, p. 99) tells it all. Mmadu is a generic, non-gendered term, and refers to all human beings, male and female alike. This means that we all are fundamentally good; all human beings have and should be treated with dignity that they necessarily deserve (Muonwe, 2018). Therefore, to regard one as unfit for an office simply on account of his or her sex, and not on what he or she has to offer, is a discrimination that attacks the fundamentals of human existence.

\section{Conclusion}

Igbo society has been traditionally patriarchal and this has affected and has continued to affect the fortunes of women in the society. The precolonial political space was dominated by men hegemony and supremacy in the greater part of Igbo society. In few towns that practised constitutional monarchy, like Onitsha and Oguta, women were given more elevated positions of authority than it was in the greater part of the society (more than $80 \%$ ) that practised direct democracy. Some towns, like Oguta, were known to have been governed by a queen, but these were isolated incidences that could hardly be justifiably used as a proof of strong political participation of women in politics in the pre-colonial era.

What this means is that women's political visibility and participation in the precolonial Igbo society is far from being an ideal as far as political inclusion along gender lines in concerned. Therefore, such authors that present it as an instance of egalitarianism and dual-sex political paradigm should pause and think it through once more, from a more nuanced and critical standpoint. 
In pre-colonial period, women's strength lay in their group solidarity. It is a credit that must not be taken away from them. The political pressure arising there from helped them in no small measure to fight for their rights in a political space where male dominance and systematic stifling of women's collective and individual talents and contributions to the political economy was rife. With their group solidarity, especially as embodied in umuada and nwunyedi groups, women effectively organized revolts, boycotts, demonstrations (ngaghari iwe), group nudity (ibo ike), and successfully "made war" on people. People have not forgotten the Ogu Umunwanyi Igbo of 1929 that jolted the then colonial masters. These group actions helped the women to challenge some unjust social and political structures in the society. Such political solidarity in the traditional Igbo society is something that Nigerian women of today must emulate, so that they can form a strong political block and force to reckon with in the society. The current situation where they have to recline on men in order to rise in their individual political careers is grossly unsustainable.

\section{Michael Muonwe}

Department of Religion \& Human Relations Nnamdi Azikiwe University, Awka makkymuo@yahoo.co.uk

\section{Reference}

Agbasiere, T. (2000). Women in Igbo life and thought. Routledge: London.

Amadiume I. (1987). Afrikan matriarchal foundations: The Igbo case. London: Karnark.

Amadiume, I. (1987).Male daughters, female husbands: Gender and sex in an African society. 
London: Zed.

Amadiume I. (1997).Re-inventing Africa: Matriarchy, religion, culture. London: Zed.

Arazu, R. (1978). A cultural model for Christian prayer. In A. Shorter (Ed.), African Christian

spirituality (112-116). London: Chapman.

Chuku, G. (2009). Igbo women and political participation in Nigeria, 1880s-2005. International Journal of African Historical Studies 42(1), 81-103.

Edeh, E. (1985). Towards an Igbo Metaphysics. Chicago: Loyola University Press.

Federal Government of Nigeria (2018). Statistical report on women and men in Nigeria.

Abuja: National Bureau of Statistics.

Henderson, R. (1972). The king in every man: Evolutionary trends in Onitsha Ibo society and culture. New Haven, CT: Yale University Press.

International Parliamentary Union (Feb. 2009). Women in national parliaments. Retrieved from http://archive.ipu.org/wmne/classif.htm.

Isiguzo, A. Ukagba, G., \& Otakpor, N. (2004). The Igbo concept of a person. Africa: Rivista Trimestrale Di Studi E Documentazione Dell'Istituto Italiano per L'Africa El'Oriente, $59 \quad$ (2), 231-243.Retrieved fromhttp://www.jstor.org/stable/40761740.

Jell-Bahlsen, S. (1998). Female power: Water priestesses of the Oru-Igbo. In O. Nnaemeka (Ed.), Sisterhood, feminism and power: From Africa to diaspora. Trenton, NJ: Africa World. 
Lebeuf, A. (2004). The role of women in the political organization of African societies. In D. Paulme, Women of tropical Africa (93-120). London: Routledge, 2004.

Luzbetak, L. (1998). The church and cultures: New perspectives in missiological Anthropology. Maryknoll, NY: Orbis.

Mba, N. (1982). Nigerian women mobilized: Women's political activity in southern Nigeria,1990-1965. Berkeley, CA: University of California Press.

Muonwe, M. (2016). New dawn for African women. Bloomington, IN: Xlibris.

Nwaguru, J. (1978). Aba and British rule: The evolution and administrative development of the old Aba divisions of Igboland 1896-1960. Enugu: Santana.

Nzegwu, N. (1995). Recovering Igbo traditions: A case for indigenous women's organizations in development. In M. Nussbaum and J. Glover (Eds.), Women, culture, and development: A study of human capabilities (445-465). Oxford: Clarendon.

(2006). Family matters: Feminist concepts in African philosophy of culture. Albany, NY: State University of New York Press.

Obiego, C. (1984). African image of the ultimate reality: An analysis of Igbo ideas of life and death in relation to Chukwu-God. Frankfurt: Peter Lang.

Okafor, S.O. (1982). Bantu philosophy: Placid Tempels revisited. Journal ofReligion in Africa, 13, 83-100.

Okeke, G. (1984). Ancestor worship among the Igbo. Communio Viatorum 27(3), 137-152.

Okeke-Ihejirika, P. (2004). Negotiating power and privilege: Igbo career women in contemporary Nigeria. Columbus, $\mathrm{OH}$ : Ohio University Press. 
Okonjo, K. (1976). The dual sex political system in operation: Igbo women and community

politics in mid western Nigeria. In N. Hafkin and E. Bay (Eds.), Women in Africa: Studies in social and economic change (45-58). Stanford, CA: Stanford University Press.

Orji, J. (2007). The end of sacred authority and the genesis of amorality and disorder in Igbo mini states. Dialectical Anthropology 31, 263-288.

Shweder, R. (2001). Rethinking the object of Anthropology and ending up where Kroeber and Kluckhohn began. American Anthropologist 103(2), 437-440.

Tanner, K. (1997). Theories of culture: A new agenda for Theology. Minneapolis, MN: Ausburg Fortress.

Uchendu, V. (1965). The Igbo of southeast Nigeria. New York: Holt, Reinhart and Winston.

UN Women (2019). Facts and figures: Leadership and political participation; available from https://www.unwomen.org/en/what-we-do/leadership-andpoliticalparticipation/facts-and-figures\#notes

Van Allen, J. (1972). Sitting on a man: Colonialism and the lost political institutions of Igbo women. Canadian Journal of African Studies 6(2), 165-181. 